\title{
Context and Cultural Understanding
}

Richard Shusterman

I

Jacob Lund, as editor of this journal, asked me to reply to Stefan Snaevarr's paper entitled "Shusterman on Europe, Entertainment, and Equality." Honored by this invitation and appreciating the considerable critical attention my pragmatist aesthetics has received from Professor Snaevarr, I feel duty bound to respond to his objections in the most direct and forthright way. The problem, however, is that I truly cannot recognize myself in the positions that Snaevarr attributes to me. This is an embarrassing confession because I have always tried to articulate my views as clearly and precisely as I could and because Stefan Snaevarr has long been an enthusiastically studious reader of my work and a friendly interlocutor. ${ }^{1}$ So if he has so seriously misrepresented my views on popular aesthetics, entertainment, and cultural identities, then perhaps he has genuinely misunderstood them because I have failed to make myself sufficiently clear. Thus, the main purpose of my response must be to correct those misrepresentations by reminding readers, including Professor Snaevarr, of what I actually wrote and meant. Once the most serious of these misunderstandings are noted, I will suggest that some general lessons about cultural understanding could be derived from them.

Snaevarr's article has two major dimensions: a critical analysis of my views on popular culture and (as evidentiary justification of his critique) an empirical survey of the traditions of popular art in Europe and their relationship to questions of social equality and political freedom. So even if Snaevarr is mistaken about my views and my seemingly arrogant "UScentrism" (S 138), his article is very helpful in reminding us of the rich traditions of popular entertainment in Europe. My remarks, however, will focus on his critical interpretation of my positions.

\section{II}

Snaevarr identifies four "hypotheses" that he finds in my pragmatist study of popular art and at which he directs his critique. 
(a) The more egalitarian a country is, the stronger the position of the popular culture within that country;

(b) American popular culture enjoys worldwide popularity because of its egalitarian style, and/or because everything American is associated with egalitarianism;

(c) Europe has no popular culture to speak of.

(d) Europe is an entity of the same kind as the US. The USA is more egalitarian than Europe. (S 130)

I do not believe I ever asserted any of these views, and I am in fact critical of all of them (especially in the way they are formulated by Snaevarr). Indeed, I have explicitly argued against most of them. Before turning to these four theses that Snaevarr attributes to me, I, regretfully, must note a substantial misunderstanding about my aesthetics still earlier in his article. Snaevarr says I defend "popular culture" as being for "ordinary folks" in the American spirit "of the common Man"(S 129). My efforts in pragmatist aesthetics were not aimed at defending popular culture in general, but rather popular art or popular aesthetics - i.e. cultural expression that consciously expresses aesthetic values, makes aesthetic claims, and often sees itself in artistic terms. Popular culture is a much wider category, including things (like McDonald's fast food) which seem neither motivated by aesthetic aims nor successful in realizing them.

More importantly, I did not define or defend popular art in terms of its representing and satisfying "ordinary folks" or "the common Man" (S 129). My pragmatist anti-essentialism vehemently resists the very idea of such "a common Man" which strikes me as a dangerous act of homogenization and reification of very different kinds of people; a reductive abstraction that, moreover, is sexist in suggesting that the male gender is the normative measure. Instead, I repeatedly insist that what defines popular art as popular is neither the allegiance with the mythical common man (or average viewer) nor the interest of the mass audience of so-called "ordinary folks." Rather, all that is needed for popularity is an audience large or multitudinous enough to secure both economic viability and a hearing in the public sphere. ${ }^{2}$

That is what rap had managed to achieve when I began thinking and writing about it as popular art in the late 1980s, when it was so remote from mainstream acceptability that colleagues described my fascination for it as criminal. Rap, heavy metal, and techno music are still not mainstream music for the common taste of ordinary folks (at least not in America); popular art, as these genres demonstrate, can even gain their popularity by 
productively diverging from and challenging the mainstream views that ordinary folks share in a society. Popular art is important to democracy because it allows the expression of eccentric, even freakish tastes, not just ordinary or common taste.

\section{III}

The major thrust of Snaevarr's critique of my alleged views is that they reflect a misinformed American chauvinism and a negatively misguided perception of Europe. Reading his critique one could take me for an arrogant parochial American who knows and cares little about Europe, except as a playground for vacations and conferences and as a useful target for critique. So, perhaps I should set the record straight about my American identity, which is distinctly not all-American. I am a bi-national whose entire university education was received outside of the United States (mostly in Israel) and was in fact completed in Europe, assuming, of course, that we consider Oxford (or more generally England) a part of Europe. (When I was at Oxford in the days of Thatcher, anti-European sentiments ran rather high. $)^{3}$

In some respects, my aesthetic theorizing about popular art is indeed American-centric. Though deploying a variety of philosophical sources from diverse traditions, my aesthetics is most deeply grounded in the tradition of American pragmatist philosophy, especially John Dewey's. ${ }^{4}$ Moreover, in discussing popular art, I devote my more detailed critical analyses to musical genres most closely associated with contemporary American culture: rap and country music. My prime reason for focusing on these genres was their dramatically increasing popularity in the American culture in which I live, and the interesting ways they illustrate aspects of pragmatist aesthetics and challenge certain dominant ideas in the philosophy of art.

I never asserted that America was the only country with a developed popular art or that it had the best popular art. Instead, recognizing the generally acknowledged (and often lamented) worldwide influence of American popular culture, ${ }^{5}$ I tried to suggest how a constellation of certain "sociohistorical factors could ... explain why it is that in America the popular arts ... have thrived and most successfully challenged high art's stranglehold on aesthetic and cultural legitimacy," thus, resisting what Bourdieu describes as the "aristocracy of culture" based on traditions of courtly aristocratic society (PL 58, 59). This does not imply that American popular art is aesthetically superior, but rather that it has been less powerfully subjugated by high culture and upper-class domination.

I never claimed that "the more egalitarian a country is, the stronger the 
position of the popular culture within that country" (Snævarr 130). Nor did I argue that America's egalitarianism is what made popular art successful there. Instead, I note a variety of factors that could explain that success, most of which Snaevarr summarizes in the beginning of his paper. In fact, I never maintained (and do not believe) that America is truly egalitarian or is appreciably more egalitarian than all the countries of Europe. I make the different claim that American ideology has traditionally been more egalitarian than the traditional ideologies of most European countries that lived through centuries of feudalism and aristocracy. Ideology, however, is not reality; and egalitarian ideology does not ensure egalitarian practices. Not only do my discussions of rap and country music critically point to oppressive inequalities and injustices in American society (racism and class prejudice), I even argue that rap music and other African-American musical genres like jazz and R\&B were able to develop so well precisely because their creators and initial target audiences suffered from severe failings of egalitarianism in the United States. The sad fact that the African-American culture and audiences that essentially created these genres did not receive equal respect had the compensating benefit that they were thus freer to develop their inspirational artistic energies outside mainstream society's cultural constraints. As I put it in Pragmatist Aesthetics, these cultures were "so brutally excluded from the dominant society that they could be largely free from the grip of its dominant aesthetic" (PA 197). This is a far cry from Snaevaar's accusation of my "maintaining that the US is a paragon of egalitarian virtues" (S 141).

My advocacy of American pragmatist philosophy and defense of some American genres of popular art is thus coupled with strong critique of American society and its failings to live up to its professed egalitarian and democratic ideals, not only in aesthetics but with respect to social and political issues. ${ }^{6}$ My general approach to American culture is similar to that which I take toward popular art - a meliorism that recognizes there is need for considerable improvement because of significant shortcomings, but that such improvement is worthwhile and possible because of the positive potential and already existing values that can be found there. My affirmations of American culture are thus tempered with strong warnings against the dangers of United States cultural hegemony.

Noting "the dangers of any one-sided cultural hegemony," I immediately add explicitly that "This includes American popular culture" (PL 59). This hegemony, I indeed suggest, is largely the product of America's military and economic might and influence rather than any intrinsic superiority of American genius. I make this point in an article for The Chronicle of Higher 
Education, entitled "The Perils of Philosophy as a Lingua Americana," where I warn against the dangers of America's increasing philosophical hegemony (while avowing that I also profit from it). ${ }^{7}$ This philosophical hegemony is expressed in their domination of the most influential publishing venues, in the increasing indifference of United States philosophers to contemporary philosophy in Europe, and in their increasing failure to master and read in the philosophically important languages of German and French, even when they are studying classic thinkers and contemporary stars who wrote in those languages. The attitude seems to be that relying on English translations is sufficient, and that what is not translated is not worth making the effort to read. This, I argue, often leads American philosophers to be less well-informed than philosophers who read in a variety of languages.

Moreover, in the more specific field of aesthetics, I have criticized the official journal of the American Society for Aesthetics (in the fifty-year celebratory issue of that same journal) for having taken "a path of increasing parochialism" by being increasingly limited in their taste for AngloAmerican aesthetics. ${ }^{8}$ Given the editorial policies of the last few decades of that journal (The Journal of Aesthetics and Art Criticism), one could hardly imagine that from the 1940s and up until 1965 it devoted considerable space and entire special issues to current aesthetics in Europe and in Asia, even occasionally printing non-English texts. Finally, in my writings on the theme of internationalism in philosophy, I have affirmed the value of an international model of multilingual dialogue while noting the dangers of internationalism through a single, dominant master language that insists on its exclusive universality. ${ }^{9}$ Though inspired in many ways by American pragmatism, my positions are very remote from those of a parochial Yankee Doodle Dandy chauvinist.

The fact that my writings on popular music are focused mainly on familiar American genres does not mean that I do not recognize the value of non-American music. I just know more about American musical culture than other musical cultures, and I prefer to write about what I know best. But the German techno scene (which I frequently enjoyed in Berlin) has also earned a place in my writing and indeed forms the opening vision and guiding inspiration for my study of the urban aesthetics of absence. Likewise, my study of hip hop reaches beyond America to invoke French rappers, whom I insist on quoting in French, even in the texts I publish in English. Moreover, in my writing on rap and country I have argued that these genres are themselves far from being purely American products, for example, by underlining the influences of African and Caribbean sources for rap, and of African, European, and Hawaiian sources for country 
music. Finally, as Snaevarr indeed admits (in a note, S 142), I recognize the important role that European popular art has played in the past, while explaining how some of its greatest popular successes evolved into high art classics: Greek tragedy, Elizabethan drama, novels of the eighteenth and nineteenth century, and cinema in the twentieth. ${ }^{10} \mathrm{I}$, moreover, underline how important European theorists have affirmed the value of entertainment or popular art, deploying the relevant views of Montaigne, Nietzsche, Gramsci, and Bahktin.

\section{IV}

As I refuse the caricature of a narrow, parochial, all-American booster, I also plead not guilty to the charge of failing to recognize the cultural complexity of Europe. In my work on internationalism in philosophy, I describe how Europe does not form a neat philosophical continent of its own but that its countries in fact belong to different philosophical power groups or empires, and that such affiliations can change over time. In exposing certain problems and misconceptions in contemporary views of multiculturalism, I criticize the use of Eurocentrism as the opposite of multiculturalism because this "belies the great cultural diversity in Europe itself, which is surely richer and deeper than the five ethno-racial categories that make up the familiar American multicultural pentagon" (PL 185). And I go on to argue that the issue of multiculturalism plays out differently in different European countries because of their cultural diversity, which, as I note, includes cultural diversity (and sometimes even linguistic diversity) within the same individual European country. Does that recognition of diversity preclude me from speaking of Europe in general? Are only Europeans allowed to speak of Europe or of European culture? They certainly do speak of these things, and if they did not, what would be the discourse and ideology of the European Union? Not only politicians but also European intellectuals (as far back as de Tocqueville) have made general contrasts between Europe and America. Of course, though we most often speak of Europe in general, we should be careful about essentialistic tendencies of generalization that mislead us into seeing important features of some major European countries as being automatically features essential to all of them. But these same essentialist dangers exist even in talking about pragmatist philosophy, which includes a variety of different perspectives that are not infrequently polemically opposed to each other. Still, I can rightly describe my aesthetics as grounded in pragmatism, even though it relies only on a limited range of pragmatist authors. 


\section{V}

I trust I have provided enough evidence to convince readers that my defense of popular art is not the expression of a narrow American chauvinism that has no respect for the European contributions to popular culture and no appreciation of Europe's cultural complexity. Let me now turn from the negativity of denials so that I can offer some positive points with respect to context and cultural understanding that emerge from Snaevarr's misunderstanding of my position, despite his clear philosophical intelligence and his basic sympathy to some of my aims with respect to aesthetics and popular art.

His misunderstanding, I think, comes from paying insufficient attention to the particular context of my argument and its sociohistorical explanations for America's seemingly greater acceptance of popular art. That context was an extended polemic against Pierre Bourdieu's rejection of the very idea of popular art as a contradiction in terms. Bourdieu (who, like pragmatism, was a formative influence on my general philosophical orientation and at whose Parisian Centre de Sociologie Européenne I wrote Pragmatist Aesthetics) based his argument against the aesthetic legitimacy of popular art on an analysis of French society, both historical and contemporary. I challenged his argument, in the most respectful manner I could, by criticizing his position for the error he typically attributed to philosophers - universalizing from one's own experience and reifying it as necessary truth instead of recognizing that artistic legitimacy depends on cultural conditions that can vary in different times and places. So, I argued for America's being more receptive to popular art than Bourdieu thought France was.

Here is how I put it in Pragmatist Aesthetics: "However compelling [his] argument may be for the French culture Bourdieu studies, it fails as a global argument against popular art. For, at least in America, such art does assert its aesthetic status and provide its own forms of aesthetic legitimation" (PA 196). I then reinforced this point by noting that "Certainly we Americans take neither philosophy nor the cultural hegemony of intellectuals as seriously as the French and other Europeans do." And I explained these differences regarding popular art and intellectual culture in terms of America's difference from France (and by extension from other European countries) in terms of the sociohistorical factors that Snaevarr tries to summarize in the beginning of his article (but that are more carefully formulated in Pragmatist Aesthetics and again in Performing Live). Toward the end of my polemic with Bourdieu, where I was explaining America's desire to escape the cultural domination of Europe (and that later seems 
reflected in the desire of Europeans to break with familiar forms of cultural domination by embracing American popular culture), I speak not of France specifically but of Europe in contrast to America. But given the evident context of my argument, the primary focus of my remarks about Europe was clearly France. ${ }^{11}$ By neglecting this context, Snaevarr misunderstood me as having a monolithic, essentialist view of Europe. But this misunderstanding can be redeemed by reminding us of the important philosophical truth that context is crucial in understanding.

This central idea is shared by pragmatism, the ordinary-language philosophy of Austin and Wittgenstein, and Bourdieu's theory of communication, which all insist that linguistic meaning is essentially contextual. I have repeatedly tried to extend this contextual perspective in treating the topics of internationalism in philosophy and of identity politics in multiculturalism by arguing that cultural identity is also essentially contextual. In Israel, for example, I was identified as an Anglo-Saxon because I was born in America with English as my mother tongue. As a student in Oxford, no one considered me Anglo-Saxon. In that context, I was obviously an Israeli or an American Jew. I have noticed how people who are identified as New Yorkers when in the States or as Brétons when in France come to be seen, respectively, as Americans or as French when travelling abroad; and their own sense of cultural identity tends to shift correspondingly with those shifting contexts. As I write in Performing Live (where I make a much more detailed case for the contextual nature of cultural identity), "One is more conscious of being a white man when one suddenly finds oneself surrounded by a large group of Japanese women" (PL 194). I suspect the multiculturalism of the Nordic countries (for example, Swedish Finns) can provide its own cases of shifting contextual cultural identities.

I try my best not to be the typical US-centric ugly American academic but rather a Euro-friendly one (who even makes the effort to give lectures in French and German). So, let me conclude with the friendly gesture of agreeing whole-heartedly with Stefan Snaevarr's assertion of the problematic complexity of European identity. ${ }^{12}$ Even determining the extension of which nations belong with Europe seems to be a problematic and contextual affair, changing according to different contexts, interests, and political pressures. That is the view of Europe I learned from my life in Israel which belongs to Europe in terms of Eurovision and basketball and soccer (it used to belong to Asian soccer but was thrown out for political reasons), but it is neither geographically part of Europe nor part of the European Union. Nor is its major language part of the Euro-Indian language group. 
Perhaps in some contexts Scandinavia is still contrasted with Europe (i.e. continental Europe), though I suspect that by now, in most contexts, it is included as Europe. I should stop here and leave this question to the Nordic intellectuals (including my friend Stefan Snaevarr) who read this journal and who know the relevant contexts here far better than I.

\section{Notes}

1. Besides the article in The Nordic Journal of Aesthetics to which I am responding (to whose pages I will refer parenthetically with the abbreviation S), Snaevarr has published other articles focusing on my work. See his "Pragmatism and Popular Culture: Shusterman, Popular Art, and the Challenge of Visuality," Journal of Aesthetic Education 41:4 (2007): 1-1 1; "The Thinker and the Rapper: Shusterman on Popular Culture," Pop Matters, an online journal, posted 5 June 2002, http:// www.popmatters.com/columns/snaevarr/020605.shtml; and an interview he conducted with me entitled "Livskunst, levende kunst," Samtiden 3 (2001): 109-115, on the occasion of the publication of Performing Live (Ithaca, NY: Cornell University Press, 2000); hereafter abbreviated as PL. Snaevarr's familiarity with my work in pragmatist and analytic aesthetics goes back to his doctoral studies, and he indeed spent a semester doing doctoral research with me at Temple University, funded by a Norwegian research grant.

2.I introduce this important distinction between a multitudinous and mass audience in Pragmatist Aesthetics: Living Beauty, Rethinking Art (Oxford: Blackwell, 1992), 190-191; hereafter this work will be abbreviated as PA. Its second edition (with a new introduction and an additional chapter on somaesthetics) was published by Rowman \& Littlefield in 2000.

3. For those interested in how my bi-national identity has shaped my philosophical work, see Richard Shusterman, Practicing Philosophy: Pragmatism and the Philosophical Life (London: Routledge, 1997), ch. 7, and "Regarding Myself and Seeing Double, Fragments of Autobiography," in George Yancey, The Philosophical I: Reflections on Life in Philosophy (Lanham: Rowman \& Littlefield, 2002), 1-25.

4. I describe some of these influences and my path to pragmatism and somaesthetics in Richard Shusterman, "Somaesthetics at the Limits," Nordic Journal of Aesthetics 35 (2008), 7-23.

5. The German cultural theorist Winfried Fluck offers a different but overlapping explanation of what he calls "the stunning worldwide resonance of American popular culture." See his "California Blue: Americanization as Self-Americanization," in Americanization and Anti-Americanism: The German Encounter with American Culture after 1945, ed. Alexander Stephen (New York: Berghahn. 2005), 221-237; quotation on 224 . 
6. For my views on democracy beyond the question of popular art, see Practicing Philosophy, chapters 2-3.

7. The Chronicle of Higher Education, August 11, 2000. B 4. In this article I also claim that American cultural dominance "seems a product of America's political, economic, technological, and military dominance."

8. Richard Shusterman, "Aesthetics between Nationalism and Internationalism," Journal of Aesthetics and Art Criticism 51 (1993): 157-167; quotation from 157. I develop this critique by also showing how American aesthetics took advantage of the European chaos of World War II and its immediate aftermath to usurp the international power of European centers of aesthetics in Germany and France. See Richard Shusterman, "Comment l'amérique a volé l'identité philosphique européenne," in L'identité Philosophique Européenne, eds. S. Douailler, J. Poulain and P. Vermeren (Paris: L'Harmattan, 1993), 253-266.

9. See the special issue of Metaphilosophy I edited, entitled "Internationalism in Philosophy" and especially its lead article, Richard Shusterman, "Internationalism in Philosophy: Models, Motives, and Problems," Metaphilosophy 28 (1997): 289-301.

10. I stress this point for example, in PA 181. Moreover, I also emphasize how important European theorists have affirmed the value of entertainment or popular art, discussing the views of Montaigne, Nietzsche, Gramsci, and Bahktin. See Richard Shusterman, "Entertainment: A Question for Aesthetics," British Journal of Aesthetics 43 (2003): 289-307.

11. When I speak of the European high culture tradition as originally shaped by "an aristocratic court and national church," I was also thinking primarily of France and the polemic with Bourdieu (though obviously other European countries also had both aristocracies and national churches). Of course, the French Revolution ended the long reign of the Catholic Church as the official state religion of France. But by then, the notion of high culture (with its aristocratic and spiritual aura) had already received its basic form or character.

12. I should also note my respect for the cultures of Asia and my recognition of their cultural differences and complexities. Such respect finds expression in such publications as "Pragmatism and East-Asian Thought," Metaphilosophy 35 (2004): 13-42; "Asian Ars Erotica and the Question of Aesthetics," Journal of Aesthetics and Art Criticism 65 (2007): 55-68; and "Definition, Dramatization, and Rasa," Journal of Aesthetics and Art Criticism 61 (2003), 295-298. 